\title{
Electromyographic Study on Shoulder Movements
}

\author{
Reimei Sugahara, M. D.*
}

Our hands, by their skill, have had a great influence on our history and culture, leading makind to prosperity. The delicate and harmonious function of the hand, controlled by the shoulder and elbow movements, enables us to do what ever we want. Particularly, the shoulder has a great flexibility due to the glenohumeral joint and scapular and clavicular movements. The intended action cannot be performed until the subtle coordination of the muscles involved is achieved. The function of the rotator cuff muscles and other participating muscles involved in the shoulder movements are so complicated and variable that the analysis of these movements up to now have been unsatisfactory. Because of this, we made an electromyographic analysis on the rotator cuff muscles and the other muscles involved in the shoulder movements. Using fine wire electrodes, the muscle action potentials were recorded on an eight channel penwriting galvanometer simultaneously. Electromyogram and joint movements were synchronized and recorded on the same plane on a $16 \mathrm{~mm}$. movie film. These film data were analysed qualitatively with a film motion analyzer.

\section{Materials and Methodes}

The dominant shoulder of nine males were tested in the current study. They understood the purpose of this study sufficiently and were trained to perform the requested movements smoothly. The standing position was mainly used. At rest the subject was in the standing position, the arms at the sides and the forearms in the natural midposition between pronation and supination. From the resting position, the following routine movements at the shoulder were performed, flexion, extension, abduction, adduction, external rotation and internal rotation. The movements were comparatively slowly performed-in an average of 4 to 5 seconds without exertion.

\footnotetext{
* Department of Orthopedic Surgery, Nihon University School of Medicine, Tokyo, Japan. (Director: Prof. Kozo Sato, M. D.)
}

The muscles tested were supraspinatus, infraspinatus, subscapularis, teres minor, teres major, deltoideus (all sections), pectoralis major (pars clavicularis and pars sternocostalis), pectoralis minor, biceps brachii (caput longum and caput breve), triceps brachii (caput longum), latissimus dorsi, coracobrachialis, trapezius (all sections), rhomboideus major, rhomboideus minor, serratus anterior (all sections) and levator scapulae.

Copper wires covered with polyurethane and 0.07 $\mathrm{mm}$. in diameter were used for the fine wire electrodes. About $3 \mathrm{~mm}$. of this wire was stripped from the tip and it was inserted into the muscle of the subject with a 27 gauge guide needle. The subject felt no discomfort from the wire electrode after withdrawal of the guide needle and for the duration of all shoulder movements. Using a pulse duration of 0.5 msec., 5 to $10 \mathrm{v}$., it was determined whether the fine wire electrode was inserted correctly into the target muscle or not. Two electrodes were inserted in one muscle about $1 \mathrm{~cm}$. apart. The

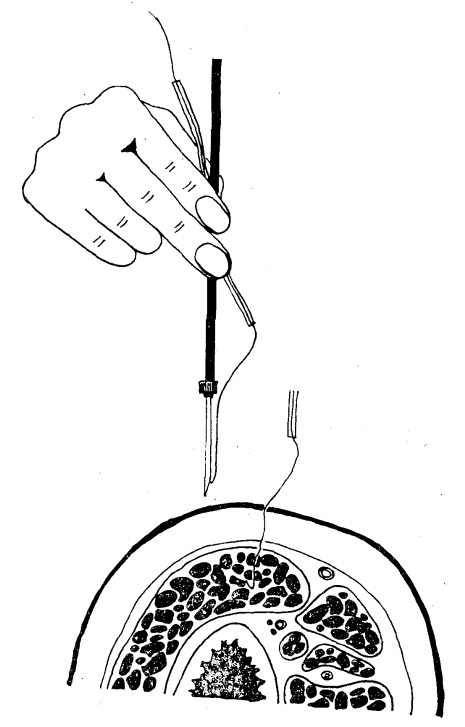

Fig. 1 Copper wires covered with polyurethane and $0.07 \mathrm{~mm}$. in diameter were used for the fine wire electrodes 


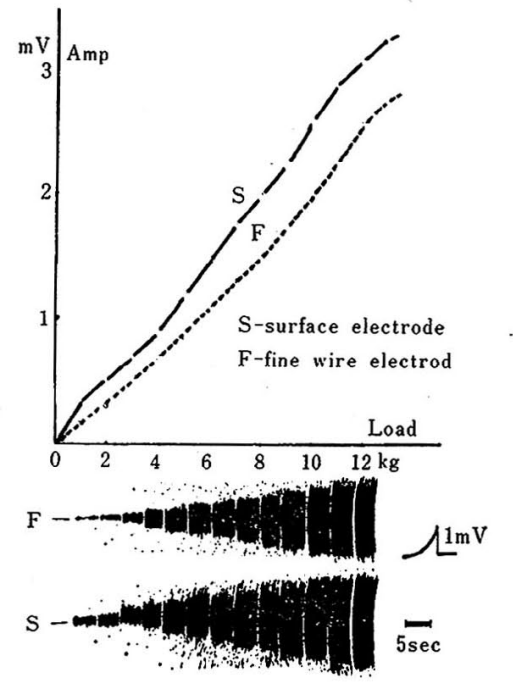

Fig. 2 Relation between muscle contraction and EMG Pattern by fine wire electrode and surface electrode

electric resistance was $20 \pm 5 \mathrm{~K} \Omega$. Our former experimental work revealed that in the isometric contraction of the biceps brachii muscle as studied with these electrodes, the amplitude of action potential was approximately proportional to a load up to $12 \mathrm{Kg}$.

An eight channel penwriting galvanometer was for the electromyographic readings.

We developed a device to record the two different phenomena (electromyography and joint movements) simultaneously. The device consisted of a $16 \mathrm{~mm}$. Arriflex movie camera equipped with two lenses of different forcal distance and a prism. The

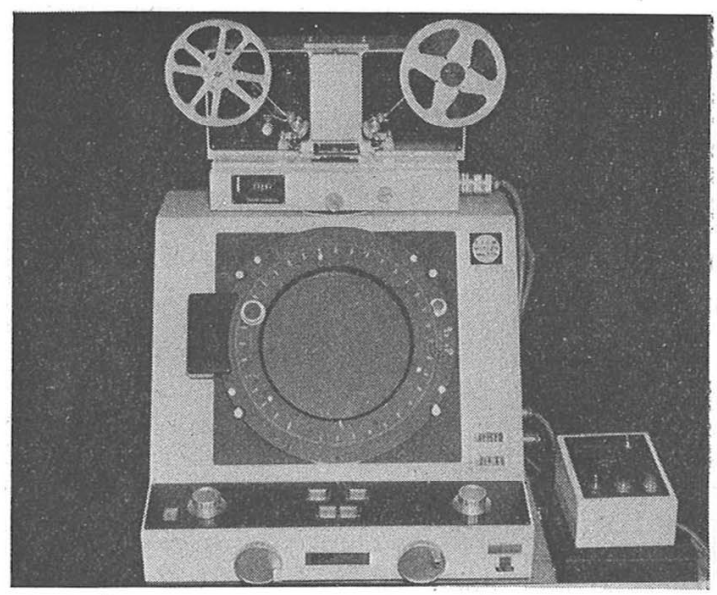

Fig. 4 Film motion analyzer

electromyogram was recorded through a $13 \mathrm{~mm}$. lens and the pattern of shoulder motion thorugh a 10 to $13 \mathrm{~mm}$. lens. They were synchronized and recorded using the prism on the same plane on 16 $\mathrm{mm}$. movie film. The correlation against time between the joint movement and the electromyogram recorded simultaneously on the same $16 \mathrm{~mm}$. movie film was analyzed qualitatively with a film motion analyzer.

\section{Result}

\section{Flexion}

At the start or a short time after the beginning of the movement, electrical activity was recorded with the supraspinatus, infraspinatus, teres minor, deltoideus (pars claviculrais), pectoralis major (pars clavicularis) and serratus anterior (all sections), and
(2)

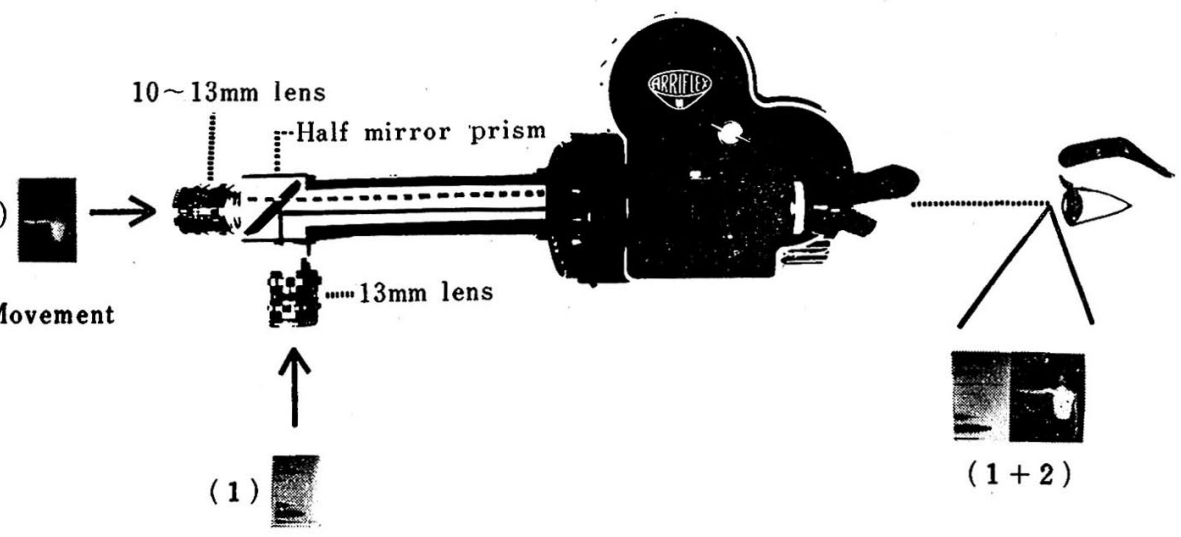

EM,G

Fig. 3 Synchronous recorder 


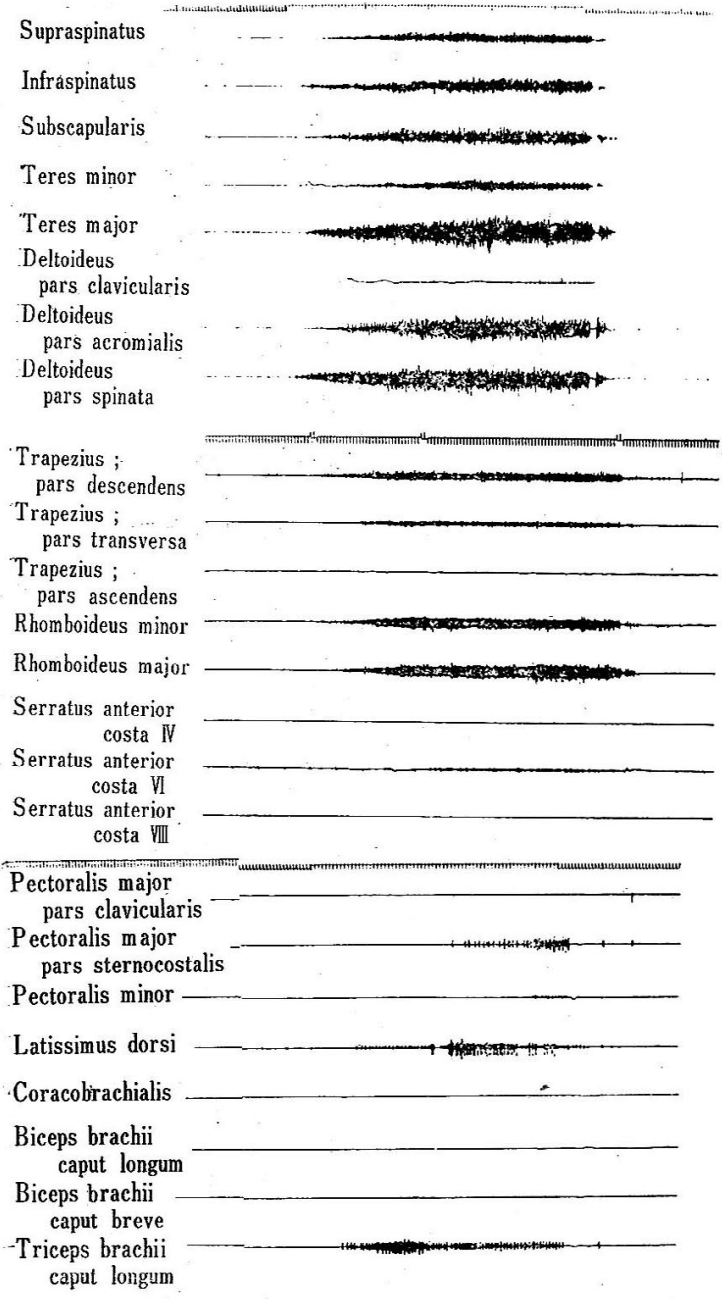

Fig. 6a Extension (Standing position)

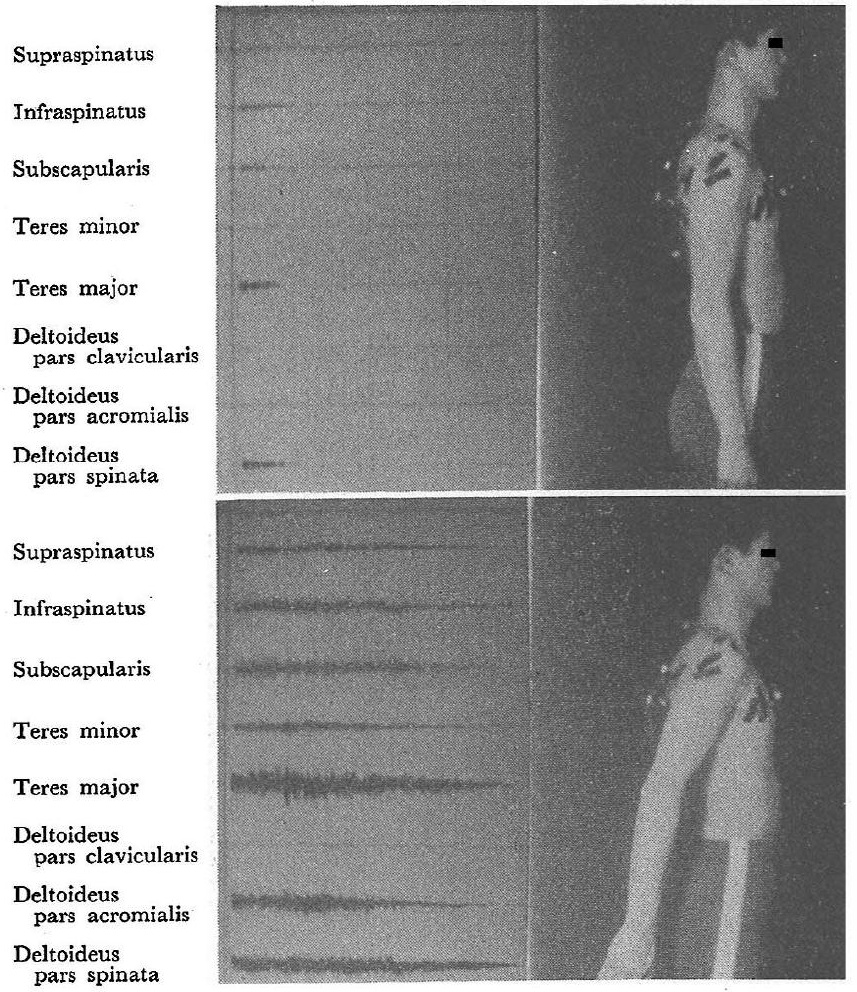

Fig. $6 \mathrm{~b}$ mialis and pars spinata), latissimus dorsi, trapezius (all sections), rhomboideus minor, rhomboideus major, serratus antcrior (central section) and levator scapulae, and sometimes with the triceps brachii (caput longum).

Other tested muscles were inactive during this movement.

\section{Abduction}

At the start or a short time afterward the movement began, electrical activity was recorded with supraspinatus, infraspinatus, deltoideus (all sections), trapezius (pars descendens) and scrratus anterior (all sections).
When the arm was elevated to 40 to 90 degrees, readings were obtained with the subscapularis, teres minor, latissimus dorsi, coracobrachialis, biceps brachii (caput longum and caput breve), triceps brachii (caput longum), trapezius (pars transversa and pars ascendens), rhomboideus major and levator scapulae.

When the arm was elevated to about 110 to 130 degrees, sometimes readings were obtained with the pectoralis major (pars clavicularis and pars sternocostalis) and pectoralis minor.

Teres major and rhomboideus minor were inactive during this movement. 


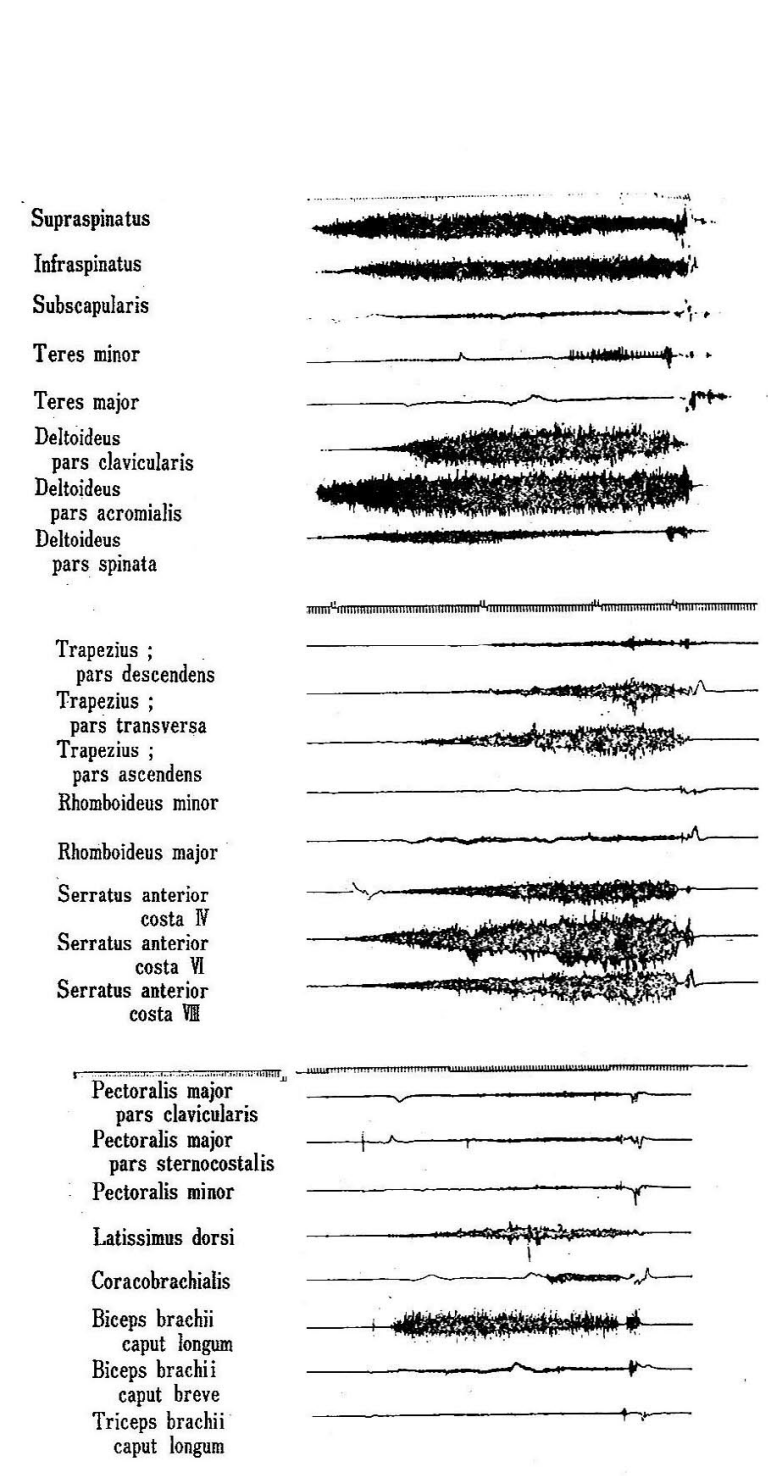

Fig. 7a Abduction (standing position)

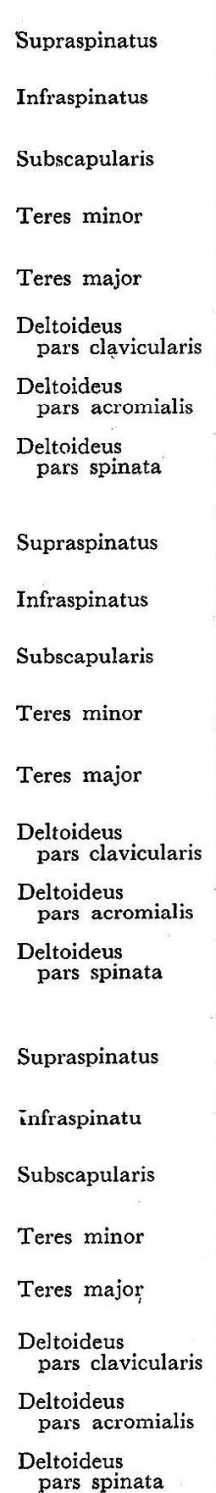

pars spinata
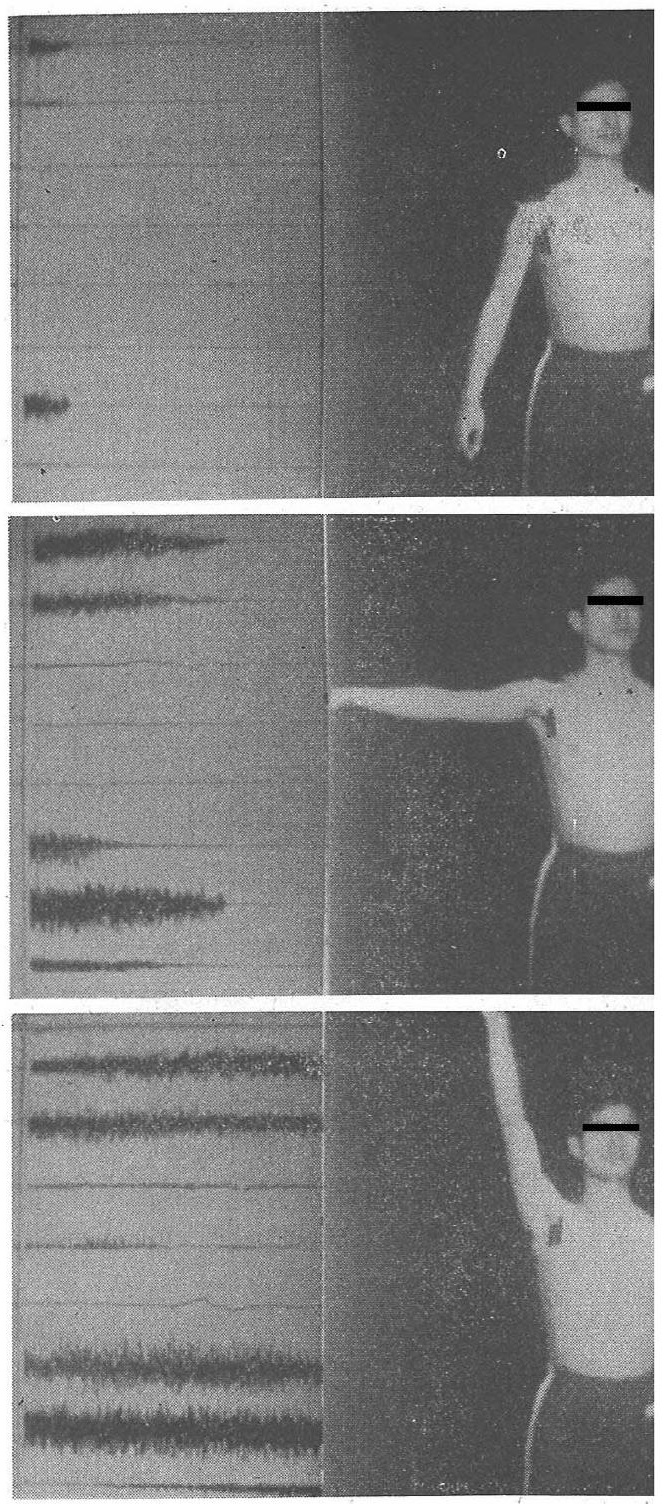

Fig. 7b

\section{Adduction}

At the start or a short time after the movement began, electrical activity was recorded with the subscapularis, teres minor, teres major, deltoideus (pars clavicularis), pectoralis major (pars clavicularis and pars sternocostalis), pectoralis minor, latissimus dorsi and coracobrachialis and sometimes with the biceps brachii (caput longum and caput breve), but the activity in the deltoideus (pars clavicularis) came a stop almost immediately.
Other tested muscles were inactive during this movement.

\section{External rotation}

At the start or a short time after the movement began, electrical activity was recorded with the infraspinatus and teres minor. During the latter half of this movement, sometimes readings were obtained with the subscapularis, teres major, deltoideus (pars acromialis), coracobrachialis, and triceps brachii (caput longum). 


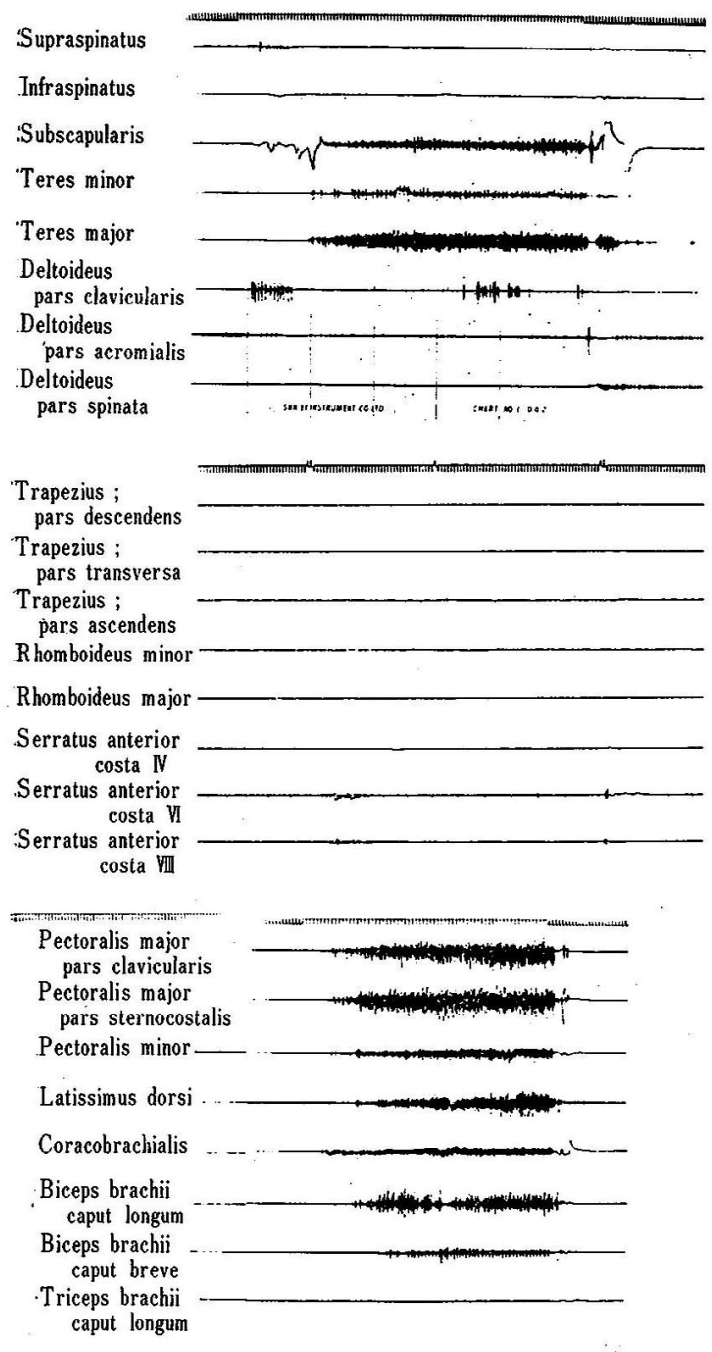

Fig. 8a Adduction (standing position)

\section{Supraspinatus \\ Infraspinatus \\ Subscapularis \\ Teres minor \\ Teres major \\ Deltoideu \\ pars clavicularis \\ Deltoideus \\ pars acromialis \\ Deltoideus \\ pars spinata \\ Supraspinatus \\ Infraspinatus \\ Subscapularis \\ Teres minor \\ Teres major \\ Deltoideus \\ pars clavicularis \\ Deltoideus \\ pars acromialis \\ Deltoideus \\ pars spinata}
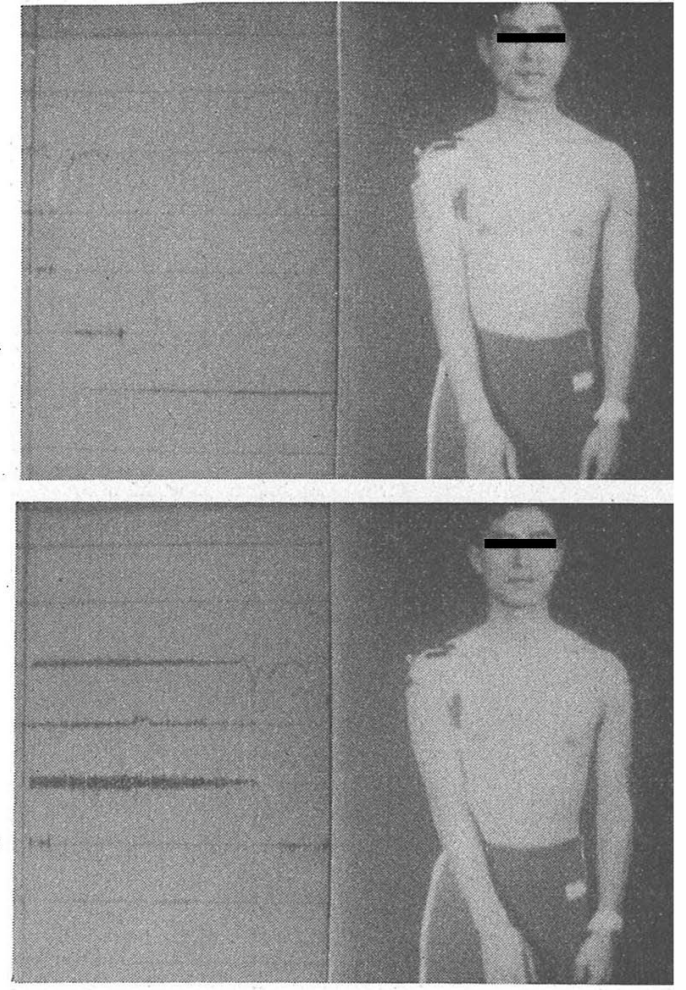

Fig. $8 \mathrm{~b}$
Other tested muscles were inactive during this movement.

\section{Internal rotation}

During this movement, electrical activity was only recorded with the subscapularis.

Other tested muscles were inactive providing there was no exertion during this movement.

\section{Conclusion}

\section{Electrode}

Copper wires covered with polyurethane and
$0.07 \mathrm{~mm}$. in diameter were used for the fine wire electrodes. This electrode has a great advantage at the study of this kind of kinesiology.

1) It can easily be inserted into or withdrawn from a muscle and the subject feel no discomfort during shoulder movements after the guide needle had been withdrawn.

2) It gives as great an electric output when inserted in a muslce as a surface electrode, and was able to pick up the action potentials of the motor 


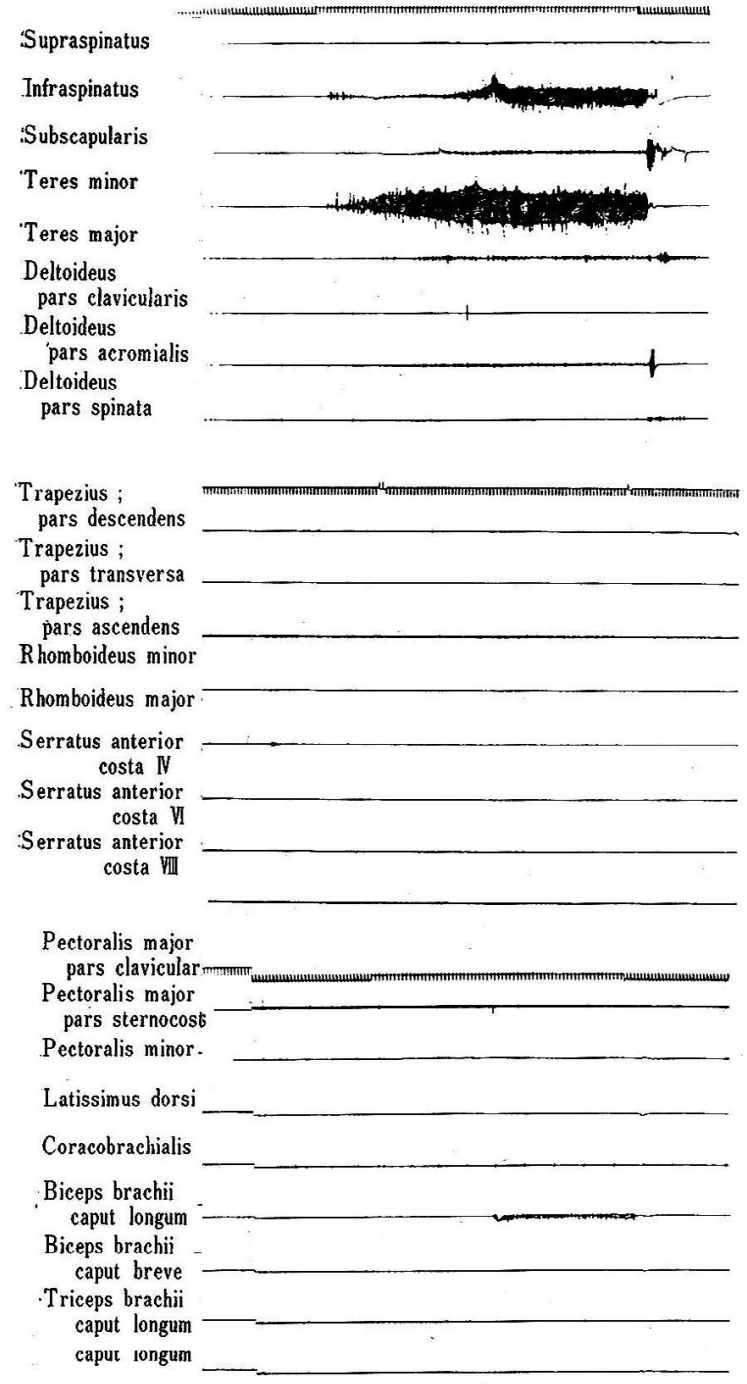

Fig. 9a External rotation (standing position)

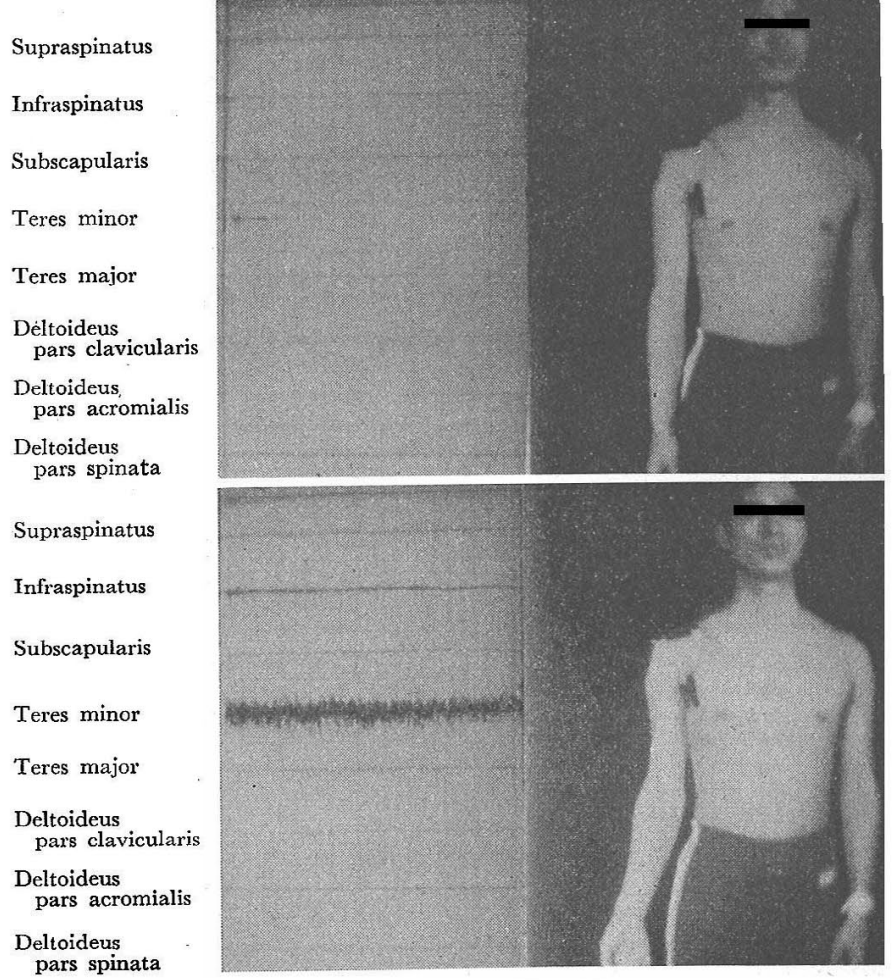

Fig. $9 b$ units of specific target muscles even when they are deep within the body.

\section{Synchronous recorder}

The synchronous recorder was able to record the two different phenomena (electromyogram and joint movements) simultaneously on a $16 \mathrm{~mm}$. movic film, and the correlation against time between the joint movement and the electromyogram was easily analyzed from the film data.

\section{Kinesiologic electromyogram}

Through various techniques we have solved most of the problems relating to the kinesiologic electromyogram, including the joining of the coarser wire to the fine wire needed for the electrode and others. However, analysis of the kinesiologic electromyogram is extremely difficult. For example, speed, resistance, type of movement and position and body characteristics of the subject involved combine sometimes give similar electric recordings, but this dose not mean the muscles are performing the 


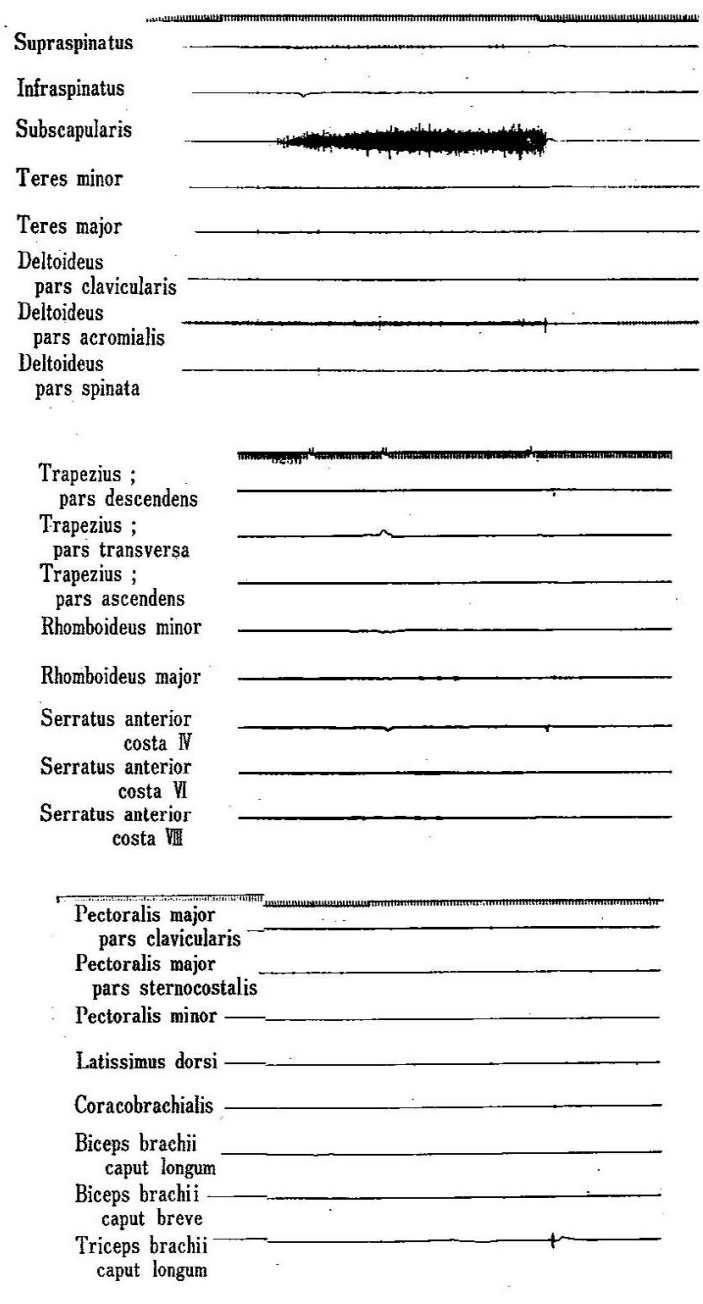

Fig. 10a Internal rotation (standing position)

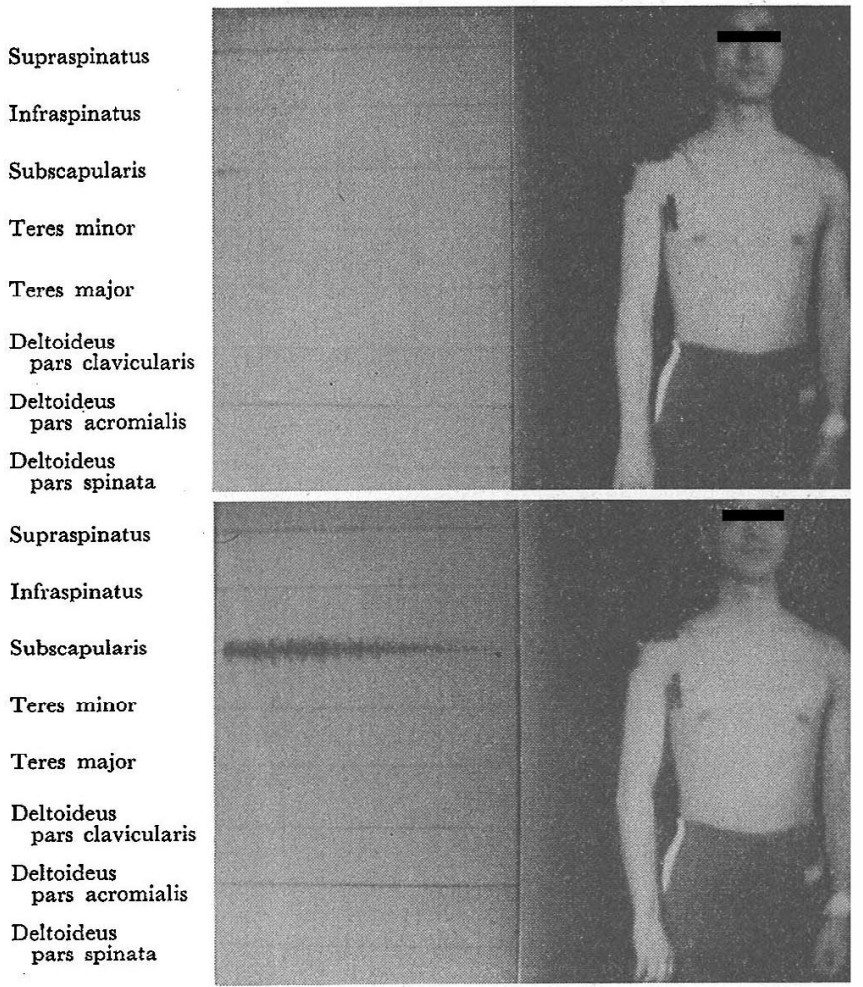

Fig. 10b same function. However, the time taken from the beginning to the end of an electric reading, and its variation in scale, of a specific muscle can be analysed.

\section{Muscles}

Supraspinatus was active during flexion, extension and abduction, and inactive during adduction, external rotation and internal rotation. This muscle could be kept at complete rest so that there would be no electromyographic reading but this was comparatively difficult. This is probably because the supraspinatus acts against the force of gravity when fixing the humeral head in the glenoid cavity. This muscle performs an important function during abduction of the arm along with the deltoideus (pars acromialis) and is active as a synergist during flexion and extension.

Infras pinatus was active during flexion, extension, abduction and external rotation, and inactive during adduction and internal rotation. This muscle performs an important function during external rotation of the arm along with the tercs minor, and 
is active as a synergist during flexion, extension and abduction. It was noted that when the arm goes through the abduction movement, the humerus rotate externally from the resting position. During the latter half of the abduction, the external rotation of the humerous allows the greater tuberosity to avoid contact with the lateral edge of the acromion by sliding under its prominence. Thus infraspinatus performs an important function in the external rotation of the humerus during abduction of the arm along with teres minor.

Subscapularis was mainly active during internal rotation, however it was slightly active during flexion, extension, abduction and adduction, and sometimes slightly active during external rotation. This muscle was the only muscle that was active during internal rotation of the arm without exertion of the shoulder movements, and was active as a synergist during flexion, extension, abduction, adduction and external rotation. Since this muscle lies between the ventral surface of the scapula and the distal portion of the serratus anterior and the lateral end is covered by the coracobrachialis and the biceps brachii (caput breve), it is difficult to make a direct study of this muscle action. Duchenne demonstrated that the action of this muscle was a internal rotation of the humerous by electrical stimulation of the scapular nerve. Geraldine Shevlin, M. and Simard, T. G. studied the function of this muscle by inserting wire electrodes beneath the medial border of the winged scapula. We examined the function of this muscle using a fine wire electrode inserted into it through the axilla avoiding the neurovascular bundle. We found that the function of this muscle was important during internal rotation of the arm and was active as a synergist during all other movements.

Teres minor was active during flexion, exten sion, abduction, adduction and external rotation, and inactive during internal rotation. This muscle did not always function the same as infraspinatus. Teres minor was particularly active during the latter half of abduction and during adduction, but infraspinatus was active during abduction and inactive during adduction.

The four muscles (supraspinatus, infraspinatus, subscapularis and teres minor) are attached around the humeral head and are called rotator cuff muscles. These rotator cuff muscles fix the humeral head in the glenoid cavity, but not all of them were active during the shoulder movements. Certain muscles came into use for specific shoulder movements. As the glenohumeral joint lacks stability, the rotator cuff muscles carry out the joint movement smoothly without fear of dislocating the humeral head.

Teres major was active during extension and adduction, and inactive during flexion, abduction, external rotation and internal rotation. This muscle was not always functioning the same as latissimus dorsi. Teres major was particularly active during extension and adduction, and slightly active during external rotation. However, latissimus dorsi was active during flexion, extension, abduction and adduction.

The three sections of deltoideus-pars clavicul aris, pars acromialis and pars spinata-were tested. Pars clavicularis was active during flexion and abduction, and was inactive during extension, adduction, external rotation and internal rotation. This muscle was slightly active at the start of adduction because the flexion movement tends to overlap at the start, thus producing a reading. Pars acromialis was active during flexion, extension and abduction, sometimes slightly active during external rotation, and inactive during adduction and internal rotation. Pars spinata was active during extension and abduction, and inactive during flexion, adduction, external rotation and internal rotation.

Detoideus is powerful when the arm is elevated (pars clavicularis is powerful during flexion and abduction, pars acromialis is powerful during abduction and latter half of flexion and pars spinata is powerful during extension), but dose not participate during internal rotation and external rotation. Each activity of these three sections differs in relation to the time taken to carry out these elevation of the arm.

Pectoralis major (pars clavicularis and pars sternocostalis) were active during flexion, adduction and sometimes slightly active during latter half of abduction. However, pars clavicularis was more active than pars sternocostalis during flexion. The two sections of the muscle were inactive during extension, external rotation and internal rotation.

Pectoralis minor was active during flexion and adduction, and sometimes slightly active during latter half of abduction, and inactive during extension, external rotation and internal rotation. This muscle comes into action during flexion and adduction of the arm when the scapula moves forward.

Latissimus dorsi was active during flexion, 
extension, abduction and adduction, and inactive during external rotation and internal rotation. This muscle was not always functioning the same as teres major.

Coracobrachialis was active during flexion, abduction and adduction, and inactive during extension external rotation and internal rotation. This muscle participated in adduction and flexion and was active as a synergist during abduction.

Bice ps brachii (caput longum and caput breve) were active during flexion, abduction and sometimes active during adduction (caput longum was more active than caput breve), and inactive during extension, external rotation and internal rotation.

Triceps brachii (caput longum) was slightly active during flexion and abduction, and sometimes slightly active during extension and external rotation, and inactive during adduction and internal rotation.

The three sections of trapezius-pars descen-

Summary of the Muscles Involved in Standing Position

\begin{tabular}{|c|c|c|c|c|c|c|c|c|c|c|c|c|c|c|}
\hline \multirow[b]{2}{*}{ Muscle } & \multicolumn{3}{|c|}{ Flexion } & \multicolumn{2}{|c|}{ Extension } & \multicolumn{3}{|c|}{ Abduction } & \multicolumn{2}{|c|}{ Adduction } & \multicolumn{4}{|c|}{ Ext. rot ation Int. rot. ation } \\
\hline & $\mathrm{S}$ & 90 & M & $\mathrm{S}$ & M & $\mathrm{S}$ & 90 & $\mathrm{M}$ & $\mathrm{S}$ & $\mathrm{M}$ & $\mathrm{S}$ & $M$ & $\mathrm{~S}$ & M \\
\hline Supraspinatus & + & + & + & + & + & + & + & + & - & - & - & - & - & - \\
\hline Infraspinatus & + & + & + & + & + & + & + & + & - & - & + & + & - & - \\
\hline Subscapurlais & - & + & + & + & + & - & + & + & + & + & - & \pm & + & + \\
\hline Teres minor & + & + & + & + & + & - & \pm & + & + & + & + & + & - & - \\
\hline Teres major & - & - & - & + & + & - & - & - & + & + & - & \pm & - & - \\
\hline Deltoideus & & & & & & & & & & & & & & \\
\hline pars clavicularis & + & + & + & - & - & + & + & + & + & - & - & - & - & - \\
\hline pars acromialis & - & + & + & + & + & + & + & + & - & - & - & \pm & - & - \\
\hline pars spinata & - & - & - & + & + & + & + & + & - & - & - & - & - & - \\
\hline Pectoralis major & & & & & & & & & & & & & & \\
\hline pars clavicularis & + & + & + & - & - & - & - & \pm & + & + & - & - & - & - \\
\hline pars sternocostalis & \pm & + & + & - & - & - & - & \pm & + & + & - & - & - & - \\
\hline Pectoralis minor & - & + & \pm & - & - & - & - & \pm & + & + & - & - & - & - \\
\hline Latissimus dorsi & - & + & + & + & + & - & + & + & + & + & - & - & - & - \\
\hline Coracobrachialis & \pm & + & + & - & - & - & + & + & + & + & - & \pm & - & - \\
\hline Biceps brachii & & & & & & & & & & & & & & \\
\hline caput longum & - & + & + & - & - & - & + & + & \pm & \pm & - & - & - & - \\
\hline caput breve & - & + & + & - & - & - & + & + & \pm & \pm & - & - & - & - \\
\hline $\begin{array}{l}\text { Triceps brachii } \\
\text { caput longum }\end{array}$ & - & + & + & \pm & \pm & - & + & + & - & - & - & \pm & - & - \\
\hline Trapezius & & & & & & & & & & & & & & \\
\hline pars desendens & - & + & + & \pm & + & \pm & + & + & - & - & - & - & - & - \\
\hline pars transversa & - & + & + & \pm & + & - & + & + & - & - & - & - & - & - \\
\hline pars ascendens & - & + & + & \pm & + & - & + & + & - & - & - & - & - & - \\
\hline Rhomboideus minor & - & - & - & + & + & - & - & - & - & - & - & - & - & - \\
\hline Rhomboideus major & - & + & + & + & + & - & + & + & - & - & - & - & - & - \\
\hline Serratus anterior & & & & & & & & & & & & & & \\
\hline upper & + & + & + & - & - & + & + & + & - & - & - & - & - & - \\
\hline central & & + & + & + & + & + & + & + & - & - & - & - & - & - \\
\hline lower & + & + & + & - & - & + & + & + & - & - & - & - & - & - \\
\hline Levator scapulae & - & + & + & + & + & - & + & + & - & - & - & - & - & - \\
\hline $\begin{array}{c}\text { S: } \\
\text { 90: } \\
\text { M: } 9 \text {-degree level of } \\
\text { M: Completion of th }\end{array}$ & $\begin{array}{l}\text { he af } \\
\text { he } n \\
\text { mov }\end{array}$ & $\begin{array}{l}\text { fter t } \\
\text { move } \\
\text { yemer }\end{array}$ & $\begin{array}{l}\text { the } n \\
\text { ment } \\
\text { nt }\end{array}$ & $\mathrm{em}$ & beg & & & $\begin{array}{l}+: \\
-: \\
\pm:\end{array}$ & $\begin{array}{l}\text { Activ } \\
\text { Inact } \\
\text { Activ }\end{array}$ & or ina & active & & & \\
\hline
\end{tabular}

Fig. 11 
dens, pars transversa and pars ascendens-were tested. All were active during flexion, extension and abduction but each activity of these three sections differs in relation to the time taken to carry out these movements. They were inactive during adduction, external rotation and internal rotation. The three sections were extremely powerful during flexi on and abduction because of the upward rotation of the scapula is carried out by this movement.

Rhomboideus minor was only active during extension, and rhomboideus major was acitve during flextion, extension and abduction. Rhomboideus major was more active than rhomboideus minor.

Three section of serratus anterior-upper, central and lower-were tested and all were active during flexion and abduction (the central section was slightly active during extension) and inactive during adduction, external rotation and internal rotation. This muscle was extremely powerful druing flexion and abduction.

Levator scapulae was active during flexion and abduction, slightly active during extension and inactive during adduction, external rotation and internal rotation.

Upward rotation of the scapula is carried out by the combined actions of trapezius and serratus anterior. Usually, upward rotation of scapula is accompanied by elevation of this bone, and these movements were carried out not only by the combined action of trapezius and serratus anterior but also by the actions of levator scapulae and rhomboideus.

All components of the shoulder girdle complex have smooth and synchronous motion when the arm is elevated. Rotator cuff muscles, deltoideus, trapezius, serratus anterior and others involved in the shoulder movements were well coordinated and the smooth, integrated movement of the humerus, the scapula and the clavicula has been termed the "scapulohumeral rhythm".

\section{Summary}

(1) Not all the rotator cuff muscles were active during the mover or synergist actions on the shoulder movements. Certain muscles came into use for specific shoulder movements. Supraspinatus performs an important function during abduction and is active as synergist during flexion and extension, but it is inactive during adduction, external rotation and internal rotation.

Infraspinatus performs an important function dur- ing external rotation and is active as a synergist during flexion, extension and abduction, but it is inactive during adduction and internal rotation. Subscapularis was the only muscle that was active during internal rotation without exertion during shoulder movements and was active as a synergist during other movements.

Teres minor porforms an important function during external rotation and extension, and was active as a synergist during flexion, abduction and adduction, and inactive during internal rotation.

(2) Deltoideus (pars clavicularis), pectoralis major, latissimus dorsi and coracobrachialis were inactive during internal rotation, and subscapuralis was the only muscle that was active during this movement without exertion.

(3) Infraspinatus and teres minor performs important function during external rotation, but deltoideus (pars spinata) was inactive during this movement.

(4) Teres minor was not always functioning the same as infraspinatus. Teres minor was particularly active during the latter half of abdunction and during adduction, but infraspinatus was active during abduction and inactive during adduction.

(5) Teres major was not always functioning the same as latissimus dorsi. Teres major was particularly active during extension and adduction, but latissimus dorsi was active during flexion, extension, abduction and adduction.

(6) It is believed that the active condition of the participating muscles differs in relation to the time taken to carry out a shoulder movement.

\section{Acknowledgement}

The author would like to express his sincere appreciation to Professor Kozo Sato of the Dept. of Orthopaedic Surgery, Nihon University School of Medicine for his valuable advice. The author also wish to thank Dr. Seji Sano and Dr. Kazuhiko Ando for thier constant guidance and encouragement through this investigation, and all members of the Kinesiology Study Group.

This paper was reported at the 7, 8 and 10th Annual meeting of the Japanese of Rehabilitation Medicine, 6th International Congress of Physical Medicine and 46th Annual Congress of the Japanese Orthopaedic Association.

\section{References}

1) Inman, V. T., Saunders, J. B. deC. M. \& Abbott, L. C.: Observations on the Function of the Shoulder Joint. J. Bone \& Jt. Surg., 26: $1,1944$.

2) Basmajian, J. V.: Muscles Alive, Their Function Revealed by Electromyography. 2nd Ed. 
The Williams \& Wilkins Co. Baltimore, 1967. 3) Brunnstrom, S.: Clinical Kinesiology. 2nd. Ed. F. A. Davis Co. Philadelphia, 1966.

4) Duchenne, G. B. A.: Physiologie des mouvements; from 5).

5) Duvall, E. N.: Kinesiology, The Anatomy of Motion, Englewood Cliffs, N. J. PrenticeHall, INC, 1959.

6) Hollinshead, W. H.: Functional Anatomy of the Limbs and Back. 2nd Ed., W. B. Saunders Co. Philadelphia \& London, 1960.

7) MacConaill, M. A. \& Basmajian, J. V.: Muscles and Movements, a basis for Human Kinesiology, The Williams \& Wilkins Co. Maltimore, 1969.

8) Steindler, A.: Kinesiology of the Human Body. 2nd Ed. Carles C Thomas, 1962.

9) Thorek, P.: Anatomy in Surgery. 2nd Ed. J. B. Lippincott Co. Philadelphia, 1962.

10) Wells, K. F.: Kinesiology, 2nd Ed. Saunders Co., Philadelphia, 1955.

11) Wright, W. G.: Muscle Function. Hafner Publishing Co. New York, 1962.

12) Freedman, L. et al.: Abduction of the arm in the Scapular Plane: Scapular and Glenohumeral Movements. A roentogenographic study, J. Bone \& Jt. Surg., 48-A: 1503, 1966.

13) Osse, J. W. M. et al.: A New Method for Insertion of Wire Electrodes in Electromyography, 12: 59, 1972.

14) Jonsson, B. \& Reichmann, S.: Displacement and Deformation of Wire Electrodes in Electromyography. A roentgenologic study, Electromyography, 9: 201, 1969.

15) Bierman, W. \& Yamshon, L. J.: Electromyography in Kinesiologic Evaluation, Arch. Phys. Med., 29: 206, 1948.

16) Van Linge, B. \& Mulder, J. D.: Function of the Supraspinatus Muscle and its Relation to the Supraspinatus Syndrome, J. Bone \& Jt. Surg., 45-B: 740, 1963.

17) Geraldine Shevlin, M. et al.: Electromyographic Study of the Function of Some Muscles Crossing the Glenohumeral Joint, Arch. Phy. Med. \& Rehabilitation, 60: 264, 1969.

18) Comtet, J. J. et Auffay, Y.: Physiologie des muscles élévateurs de l'épaule, Revue de Chirugie Orthopedique, 56: 105, 1970.

19) Simard, T. G.: Méthode D’études Électromyographiques des Muscles Périscapulaires chez L'adulte Normal., Union Medicale du Canada, 100: 723, 1971.

20) Broome, H. L. \& Basmajian, J. V.: The Function of the Teres Major Muscle: an Electromyographic Study, Anat. Rec., 170: 309, 1971.
21) Wertheimer, L. G. \& Ferraz, E. C. D. F. Folia clin. et biol., 28: 276, 1958. Trans. Basmajian, J. V. Muscles Alive.

22) Scheving, L. E. \& Pauly, J. E.: An Electromyographic Study of Some Muscles Acting on. the Upper Extremity of Man, Anat. Rec., 135: 239, 1959.

23) Machado de Sousa, O. Fasto Berzin \& Berardi, A. C.: Electromyographic Study of the Pectoralis Major and Latissimus Dorsi Muscles During Medial Rotation of the Arm., Electromyography, 9: 407, 1969.

24) Brunnstrom, S.: Comparative Strength of Muscles with Similar Function: A Study on Peripheral Nerve Injuries of the Upper Extremity, The Physiotherapy Review, 26: 59, 1946.

25) Thom, H.: Elektromyographische Untersuchungen Zur Funktion des M. trapecicus, Elektromedizin, 10: 65, 1965.

26) Yamshon, L. J. \& Bierman, W.: Kinesiologic Electromyography II. The Trapezius, Arch. Phys. Med., 30: 286, 1949.

27) Bearn, J. G.: An Electromyographic Study of the Trapezius, Deltoid, Pectoralis Major, Biceps and Triceps Muscles, During Static Loading of the Upper Limb, Anat. Rec., 140: 103, $1961 \mathrm{~b}$.

28) Wiedenbauer, M. M. \& Mortensen, O. A.: An Electromyographic Study of the Trapezius Muscle., Am. J. Phys. Med., 31: 363, 1952.

29) Ogata, T.: The Studies on the Muscles for the Movement of Shoulder Joint, using the Action Current. Japanese J. Anthrop. Soc. Nippon.

30) Tsuyama, N. \& Suzuki, R.: Electromyogram, Practical Application to the Orthopaedic Surgery. (in Japanese) Igaku no Doko, 7: 87, 1956.

31) Tsuyama, N.: Clinical Kinesiology on the Electromyogram., (in Japanese) No. 15 Nihon Igakukaisokai Gakujutsushukai Kiroku 5: 379, 1959.

32) Tsuyama, N.: Kinesiology of the Upper Limb: Reconstractive Surgery of the Shoulder girdle \& Elbow. (in Japanese) J. Jap. Orthop. Ass., 47: $377,1973$.

33) Okamoto, T. et al.: Electromyographical Study of the Extension of the Upper Extremity, (in Japanese) Japanese J. physical Fitness, 15: $37,1966$.

34) Okamoto, T. et al.: Electromyographic Study of Elevation of the Arm, Research Journal of Physical Education, 11: 127, 1967.

35) Tsurudome, H.: Electromyographic Study on the Index Finger Movements by Means of Synchronous Recorder. in Japanese Nihon Univ. J. Med. 26: 1245, 1967. 


\section{<和文 抄 録>}

\section{肩運動の筋電図学的研究}

日本大学医学部整形外科学教室

（主任 佐藤孝三教授）

菅原黎 明

肩運動は大きな運動域をもつが，これは肩関節と肩甲 骨と鎖骨の総合された動きによりもたらされる。古来よ り肩運動に関与する rotator cuff muscles を始め多くの 関与筋群の活動動態は検索されて来た。しかしながら肩 運動は多様にして複雑なために今まで十分な解明はなさ れていない。この様な観点に立脚して rotator cuff muscles を始め肩運動に関与する筋群の活動動態を筋電図を 用いて分析した。

健康男子 9 名の利き肩を用い，主として立位に特々る 前方挙上, 後方挙上, 外方挙上, 内方挙上, 外旋叔よび内旋 の各運動を行なわせた。被検筋は棘上筋，棘下筋，肩甲 下筋，小円筋，大円筋，三角筋各部，大胸筋鎖骨部括よ び胸骨部，小胸筋，上腕二頭筋長頭执よび短頭，上腕三 頭筋長頭, 広背筋, 烏口腕筋, 僧帽筋各部, 大圭よび小 菱形筋，前鋸筋扮よび肩甲挙筋の各筋である. 電極は po lyurethane coating してある直径 $0.07 \mathrm{~mm}$. の銅線を fine wire electrode として用いた。 8 チャンネル筋電計を用 い, 得られた筋電図と関節運動は 2 現象同時撮影装置に より $16 \mathrm{~mm}$. 映画フィルム上に同時記録した。 このフィ ルムは Film motion analyzer を用いて定性分析された。 結 果

1) rotator cuff muscles はすべての管が常時 mover あ るいは synergist として関与するのではなく関節運動の方 向によりそれぞれ特定の筋群が適時作動すると思われる.

2) 三角筋鎖骨部, 大胸䇗, 広背筋, 烏口腕筋に和いて は内旋作用は認められなかった。 また肩甲下笳は特別な 負荷そ加えない内旋時において唯一の活動筋である.

3）棘下笳と小円筋は外旋時に重要な機能を有するが, 三角筋肩甲棘部にはこの作用は認められなかった。

4）小円筋と棘下筋との間には若干の機能的な差異が ある.すなわら小円筋は外方挙上の後半と内方挙上時に 関与するが，䊂下笳は外方挙上に 関与するが内方挙上時 には関与しなかった。

5) 大円筋と広背筋との間には若干の機能的な差異が ある・すなわち大円筋は後方挙上と内方挙上時に 㗢くが 広背筋は前方挙上, 後方挙上, 外方挙上, 内方挙上時飞 㗢く.

6) 関与筋群の活動動態に若干の経時的差異を認めた.

\section{新现

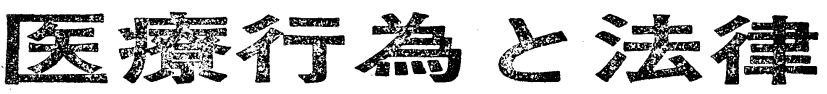

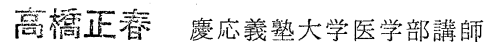

\section{织A5 頁230 $1973 \quad ¥ 1,900 \quad$ †170}

最近，いわゆる医事紛争が多発し，医 療行為における医師と患者との関係は 複雑晸妙なものとなつてきている。本 書は，医師（医療関係者）之患者(ひ ろくは国民）の医療行為にかかわる法 律関係を明確に把握することによつて それぞれが相互の立場を理解し, 紛争 を末然にふせぐ一助となることを目的 として書かれた。とくに判例を多くあ げて, 診療過誤に重点をおいて解説す る。また，民法，刑法などに関係する すへてての医療行為についてもふれ，に 療関係者にも患者の側にも理解できる ようわかりやすく述べる。

\section{[主要内容]}

診療行為の法的性質 診療行為が適法とされる理由 診療契約 契約の一般 原則々䛦療契約の特性／契約の種類——診療契約はどんな契約か／診療契約 の䋨結，診療契約にもとづく医師の義務／診療契約にもとづく患者の義務／ 診療契約の終了 辜務管理——依頼のない診療行為 事務管理における義務 医蒸行為の当事者 医師／医療補助者の義陊と医業／医師の本分／医師の権 利と義務(医師法上における) 害者の秘密の保持 秘密しはなにか/秘密 の漏浛と刑法/秘密の膤泄と医源関係法規/秘密の保持はこの限度にまで保 たれなければならないか／秘密の保持を履行させるための保証 診断害頡

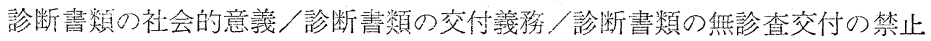

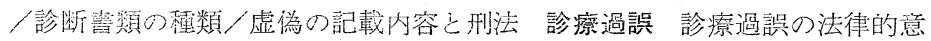

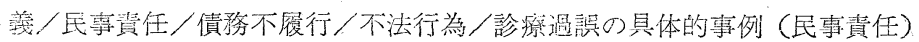

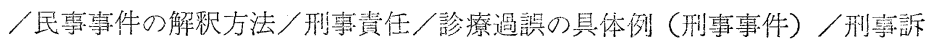
訟の手湏 /骖療過誤に対する行政処分 